\title{
The Case Against the Politicization of Psychiatry: à Propos the Goldwater Rule
}

\author{
Gabriel Andrade ${ }^{\bowtie}$ \\ College of Medicine, Ajman University, United Arab Emirates
}

In a past issue of Psychiatry Investigation, Seon-Chol Park discusses the so-called Goldwater rule. This rule states that "it is unethical for a psychiatrist to offer a professional opinion unless he or she has conducted an examination and has been granted proper authorization for such a statement."

Of late, this rule has been challenged, because it is often argued that the election of Donald Trump as President requires its reconsideration, inasmuch as he may not be mentally stable, and that is dangerous for the world. ${ }^{2}$ This case has been most emphatically made by the authors of The Dangerous Case of Donald Trump, a collection of articles and essays authored by psychiatrists, psychologists, and other commentators, who explain why they believe Donald Trump is mentally unfit, and should therefore be removed from office.

It is important to note that these authors, by doing that, ultimately break the Goldwater rule, and this is ethically irresponsible and unprofessional. So, that particular book is at fault for politicizing psychiatry, but also for violating a fundamental rule in the ethical practice of psychiatry. Whenever the Goldwater rule is violated, this constitutes an instance of the politicization of psychiatry. Recall that the whole purpose of the Goldwater rule is to avoid unfounded diagnoses (in the absence of clinical interviews) of public figures. The original proponents of the Goldwater rule came up with this concept, given that in 1964, Fact magazine had published an article labeling presidential candidate Barry Goldwater with all sorts of mental disorders. This was done with the sole intention of politically discrediting Goldwater. That is how the violation of the Goldwater rule is fundamentally politicizing psychiatry.

Received: February 16, 2020 Revised: February 20, 2020

Accepted: March 25, 2020

$\triangle$ Correspondence: Gabriel Andrade, $\mathrm{PhD}$

College of Medicine, Ajman University, Al Jurf Complex Ajman 346, United Arab Emirates

Tel: +9714562552, E-mail: Gabrielernesto2000@gmail.com

(c) This is an Open Access article distributed under the terms of the Creative Commons Attribution Non-Commercial License (https://creativecommons.org/licenses/by$\mathrm{nc} / 4.0$ ) which permits unrestricted non-commercial use, distribution, and reproduction in any medium, provided the original work is properly cited.
Park $^{3}$ believes that "phenomenological approaches are needed to understand a patient's subjective experience in the era of DSM-5... the Goldwater rule may be partly supported by the phenomenological perspective." He therefore provides good reasons why the Goldwater rule should be upheld.

I would like to offer some additional reasons why the Goldwater rule needs to be upheld. It is important to keep in mind that breaching the Goldwater rule contributes to the politicization of psychiatry, and this medical specialty has a troublingly long history of political abuse. Using psychiatric jargon to score political points against a public figure, is dangerously close to the kind of politicization of psychiatry that was all too common in the Soviet Union, and continues to be the case in Russia and China.

In his great work on the history of psychiatry, Madness and Civilization, Michel Foucault reminds us that psychiatry's own origins, were imbedded in political maneuvers. By the 17th Century, people were massively interned in institutions throughout Europe, not always because they suffered mental illnesses, but rather, because they were a nuisance to the political regime: debtors, vagrants, petty criminals, and religious dissenters. In Foucault's words, "in this great confinement of the classical age, the essential thing-and the new event-is that men were confined in cities of pure morality, where the law that should reign in all hearts was to be applied without compromise, without concession, in the rigorous forms of physical constraint. Morality permitted itself to be administered like trade or economy."

This gives occasion to think that given its own origins, psychiatry needs to be extra careful in not allowing itself to be abused for political purposes. Unfortunately, for much of the 20th Century, psychiatry was abused by various totalitarian regimes. Psychiatry is useful for totalitarian regimes, because when psychiatrists have the power to hospitalize, political dissenters can be interned, with no need of a trial. And, once these dissenters have clinical labels, the rest of the population will not take their views seriously. 
We would be naïve to think that this kind of abuse can never happen in democratic societies, such as South Korea. The United States itself has a history of these types of practices. For example, occasionally, whistleblowers from powerful institutions in the United States, both in the private and public sector, have also been labeled with mental disorders (sometimes even without direct psychiatric interviews), presumably under the pressure of powerful lobbies that have been exposed by those whistleblowers. ${ }^{5}$

And, precisely because democratic societies also run the risk of using psychiatry as a political tool, we must be very careful to regulate the way we use psychiatric terminology and diagnoses, when talking about political figures. That is why we need to continue to support the Goldwater rule.

This does not mean that psychiatrists are not entitled to have political opinions. Furthermore, in democratic societies, they are free to voice these opinions. But it is very important for them to understand that they can only express these opinions as citizens, not as psychiatrists. When commenting about politics, they must not wear the white coat, so to speak. A democracy would allow psychiatrists to come out and speak about political issues, but democracy would discourage them from doing so under the protective cloak of psychiatry.

If a politician is to be confronted, that must take place in the political arena, not in the clinical realm. Let us remember that totalitarianism is built by degrees, and what may begin as a seemingly mild tendency to label a politician with a particular diagnosis, can eventually lead us to the abuses that took place in the Soviet Union. The Goldwater rule is a useful piece of regulation that prevents psychiatry from going down that path.

Psychiatrists would do better, if they followed the example provided by Allen Francis, in Twilight of American Sanity: A Psychiatrist Analyzes the Age of Trump. In that book, he takes to task, not President Trump himself, but rather, the society that elected him as President. In fact, while strongly criticizing Trump, Frances considers that the Goldwater rule must be upheld, and consequently refuses to label Trump with a disorder, precisely because he had never conducted a psychiatric interview with him. He eloquently writes: "I saw no evidence that Trump had a mental disorder and, even if I did, the American Psychiatric Association has a useful ethics policy [the Goldwater rule] that explicitly prohibits the armchair diagnosis of politicians... I had no desire to register my political disapproval and personal distaste for Trump via psychiatric name-calling." ${ }^{16}$ One can criticize Trump (or any other politician) on ideological and political grounds, but as Frances very well recommends, the clinical jargon should not be used, as per the Goldwater rule.

Unfortunately, some psychiatrists in the United States have engaged in this type of politicization. The way they have ap- proached the mental health of Donald Trump without a proper clinical interview (thus violating the Goldwater rule) is the best example of a case of a link between the politicization of psychiatry due to the violation of the Goldwater rule.

Psychiatric comments on Trump's mental status are deeply embedded in speculation. For example, Schwartz ${ }^{7}$ speculates about Trump's childhood events forming his personality, and Wrubble ${ }^{8}$ speculates about Trump's mental illness being rooted in his relationship with his father. Unsurprisingly, amongst psychiatric commentators of Trump's mental status, there is little agreement about what his exact diagnosis is. All of this constitutes a politicization of psychiatry, inasmuch as clinical diagnoses with no empirical bases whatsoever (in the absence of a clinical interview) are used to score political points against a president currently in office. As the case of the diagnosis labeled on Trump confirms, this is psychiatry in the service of politics, and not truly in the service of science.

In conclusion, it can be asserted that violation of the Goldwater rule leads to politicization of psychiatry. The case of Donald Trump proves as much. The current United States President may be criticized (or defended) on many fronts (that is beyond the scope of this article). But, if psychiatrists opt to violate the Goldwater rule by issuing diagnoses without ever doing a clinical interview, they are guilty of politicizing psychiatry, and this may be a dangerous step towards totalitarianism. Psychiatrists all over the world need to consider this risk, so that in each country, versions of the Goldwater rule are honored, and thus avoid politicization of this medical specialty.

\section{Conflicts of Interest}

The author has no potential conflicts of interest to disclose.

\section{ORCID iD}

Gabriel Andrade https://orcid.org/0000-0001-8053-072X

\section{REFERENCES}

1. American Psychiatric Association. Ethics. Available at: https://www. psychiatry.org/psychiatrists/practice/ethics. 2017. Accessed Dec 28, 2019.

2. Lee B. Introduction. In: Lee B, Editor. The Dangerous Case of Donald Trump. New York: Thomas Dunne; 2009

3. Park SC. The Goldwater rule from the perspective of phenomenological psychopathology. Psychiatry Investig 2018;15:102-103.

4. Foucault M. Madness and Civilization. New York: Knopf; 2013.

5. Lennane J. What happens to whistleblowers, and why. Soc Med 2012; 6:249-258.

6. Francis A. Twilight of American Sanity: A Psychiatrist Analyzes the Age of Trump. New York: William Morrow; 2017.

7. Schwartz T. I Wrote the Art of the Deal with Donald Trump. In: Lee B, Editor. The Dangerous Case of Donald Trump. New York: Thomas Dunne, 2019, p.69-74.

8. Wrubble S. Trump's Daddy Issues. A Toxic Miss for America. In: Lee B, Editor. The Dangerous Case of Donald Trump. New York: Thomas Dunne, 2019, p.350-355. 